\title{
Distribution, morphology and habitats of saline wetlands: a case study from Monegros, Spain
}

\author{
C. CASTAÑEDA ${ }^{(1)}$ J. HERRERO ${ }^{(1)}$ J.A. CONESA ${ }^{(2)}$
}

\section{${ }^{(1)}$ Estación Experimental de Aula Dei (CSIC)}

Avda. Montañana 1.005 - 50059, PO Box 13034, 50080 Zaragoza, Spain. Castañeda Email: ccastaneda@eead.csic.es Herrero E-mail: jhi@eead.csic.es, Phone: +34976716069 Fax: +34 976716145

${ }^{(2)}$ Departamento de Hortofruticultura, Botánica y Jardinería, Universitat de Lleida Av. Rovira Roure 191, 25198 Lleida, Spain. Conesa E-mail: conesa@hbj.udl.cat, Fax: +34 973702099

\begin{abstract}
Wetlands in semiarid regions have received less attention than wetlands in humidtemperate areas, and the limited amount of information has resulted in little regulatory recognition. A comprehensive map of the saline wetlands that occur in karstic depressions in the semiarid region of Monegros, NE Spain, was developed from historical data, topography, and surveys of vascular flora. Playa-lakes and other saline depressions are expressions of solution dolines largely founded on groundwater dynamics and favored by the limestone and gypsum-rich substrate. Substrate composition, groundwater dynamics, and the network of infilled valleys are key factors in the distribution of the wetlands. In spite of the anthropogenic imprint, wetlands morphometrics are the expression of geological processes. Significant correlations were found between basin area and depth, and between
\end{abstract}


elongation and substrate composition. The predominantly subelongated shape of the Monegros saline wetlands (MSW) reflects their origin and a geometry strongly influenced by fractures. Grouping the MSW based on geological and vegetation features, provide a predictable relationship of surficial processes with the occurrence of otherwise complex and undetectable hydrological connectivity. Our ten geologybased Groups showed a high intra-group variation in depth, elongation, and vegetation cover. The eight vegetation-based categories mirror the gradation in flooding frequency and the soil salinity of MSW. The significant contrasts existing in-between the groups of wetlands and the disclosure of their causal factors provides a functional perspective at the landscape scale. This approach will help to monitor the ongoing environmental alterations associated with new on-farm irrigation developments.

Keywords Desert. Endorheic. Halophytes. Karstic. Playa-lake.

\section{INTRODUCTION}

Wetlands are striking features of the landscape when they occur in deserts or other drylands where water deficit strongly constrains life. Worldwide, most saline wetlands occur in arid countries and host animals, plants, and microorganisms adapted to extreme conditions such as hypersalinity, high solar radiation, temperature extremes, and irregular, alternating 
periods of drought and flooding. Saline lakes from drylands account for a similar proportion of world water (about $0.008 \%)$ than freshwater lakes $(0.009 \%)$ from humid areas (Ramsar Convention Secretariat, 2010). Some of the best-known inland saline wetlands include those of Australia (Bowler, 1986; Dugid et al., 2002; McEwan et al., 2006; Tweed et al., 2011) and those in the southwestern parts of the US (Lines, 1979; Senger et al., 1987; Stafford et al., 2008). Unlike most of the wetlands in temperate-humid regions, the ecosystems of saline wetlands in arid environments rely on intermittent flooding with saline water. Then, the anthropogenic inputs of freshwater to those wetlands pose one of the various threats to salt lakes, as reviewed by Williams (2002). Traditionally, saline wetlands have been scorned for being unproductive and often ignored in inventories of wetlands (Hollis, 1990). In the last century, saline wetlands have become an environmental concern; usually, only because they provide habitats for wintering and breeding birds. The dearth of saline inventories of wetlands, and maps of soil and vegetation, has prevented the understanding of saline wetlands evolution.

In Western Europe, only Spain has natural inland saline wetlands in arid and semi-arid environments (Williams, 1996, 2002). About 10\% of Spanish Ramsar sites are inland saline wetlands. The uniqueness of the saline wetlands scattered throughout Monegros, NE Spain, has been recognized for some time (Dantín, 1929, 1942) and they provide habitat for rare and threatened plants, animals, and microbes according to the review of Pedrocchi (1998) and the inventory of habitats of Conesa et al. (2011). Several of the geologic, hydrologic, and edaphic characteristics of those wetlands have been addressed during the last decades (e.g. Pueyo, 1978/79; Samper-Calvete and García-Vera, 1998; Sánchez et al., 1998; Schütt, 1998; Valero-Garcés et al., 2001; Gutiérrez-Elorza et al., 2002; Castañeda and Herrero, 
2005; Herrero, 2008; Mees et al., 2011; Domínguez et al., 2013a). Meanwhile, many of the Monegros saline wetlands (MSW) have been degraded. Centuries-old agriculture and new on-farm irrigation developments (Castañeda and Herrero, 2008; Domínguez et al., 2013b) have led to geomorphic and hydrologic changes that have blurred many features of the landscape.

The present study undertakes a comprehensive approach to the MSW distribution pattern, aimed at understanding their natural functioning as a system before modification by irrigation. For this purpose we follow two main steps: i) to recognize and delimit MSW as functional saline depressions based upon topography and vegetation, and ii) to characterize the distribution of wetlands using geological and physiographic criteria, and analyzing their morphometrics. The results of this study indicate the extent to which a multidisciplinary approach applied in similar environments is significant to understand the functions of wetlands and their response to changes in land use.

\section{STUDY AREA}

The Monegros saline wetlands $\left(41^{\circ} 25.5^{\prime} \mathrm{N}, 0^{\circ} 9.9^{\prime} \mathrm{W}\right)$ are $\sim 70 \mathrm{~km}$ southeast of the city of Zaragoza, within the semiarid Central Ebro Basin, NE Spain. Mean temperature is $14.9^{\circ} \mathrm{C}$. Low rainfall $\left(\mathrm{mean}=334 \mathrm{~mm} \mathrm{yr}^{-1}\right)$ and high evaporation (mean reference evapotranspiration

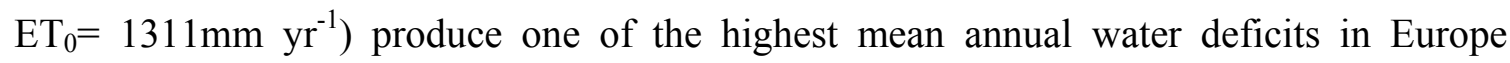
(Herrero and Snyder, 1997). The highly erodible soils of the area are exposed to frequent 
winter NW winds blowing at $>10 \mathrm{~m} \mathrm{~s}^{-1}$ a $20 \%$ of days every year (all data from "Valfarta" meteorological station, for the period 2004 to 2012).

More than a hundred saline wetlands (Castañeda et al., 2005) are scattered across a Miocene structural platform ( $400 \mathrm{~m}$ a.s.1.) that lies $200 \mathrm{~m}$ above the Ebro River. This platform grades slightly $\left(1^{\circ}-2^{\circ}\right)$ to the North and is sharply delineated by escarpments on the south side. The platform exhibits a high density (absolute maximum of $8.36 \mathrm{~km} \mathrm{~km}^{-2}$ ) of lineaments, most of them corresponding to normal faults, with a dominant NW-SE orientation (Quirantes, 1965; Arlegui and Soriano, 1998). A secondary set of NE-SW lineaments (less than 5\%) developed in the western sector of the platform. The Zaragoza Gypsum Formation constitutes the near-horizontal strata of the platform (Quirantes, 1978); gypsum and limestones are predominant in the area and are interbedded with lutites and marls (Fig. 1). The vertical and lateral alternation of these lithologies contributes to the hydrogeological complexity of the area. Typic Haplogypsids, Typic Haplocalcids, and Gypsic Aquisalids (See Soil Survey Staff, 2010 in the taxonomy of the soils) are the most common soils of the depressions, whereas Typic Calcigypsids are found on slopes and plains.

The karstification of the bedrock has formed depressions and solution dolines, some of them dated from $\sim 24000$ years BP (González-Sampériz et al., 2008). The excavation of the closed basins by karstification and deflation (Sánchez et al., 1998) has been counteracted by infilling with the materials transported by the sporadic $[<10 \%$ of the rainfall (SamperCalvete and García-Vera, 1998)] but erosive surface runoff. Saline wetlands occur at the bottom of the depressions. They show a variety of habitats, from playa-lakes to small saline 
basins, and can be identified by means of different vegetation, soil, and hydrology indicators (Brostoff et al., 2001). They host ephemeral brines and waterlogged to moist soils, even in periods of hydric deficit, due to the proximity of a permanent shallow water table. The drivers of the high salinity of the groundwater $\left(>100 \mathrm{~g} \mathrm{~L}^{-1}\right)$ are; i) dissolution of soluble salts occurring in the geologic materials (especially in lutites), ii) high evapotranspiration (3.44mm/day, Castañeda and García-Vera, 2008), and iii) long residence time, between 10 and 100 years (García Vera, 1996; Samper and García Vera, 1998). Half of the water input into the wetlands comes from rains, a $40 \%$ from groundwater, and a $10 \%$ from surface runoff (Castañeda and García-Vera, 2008).

Vegetation around the typically bare floors of the playa-lakes consists on a complex fringe of perennial and annual halophytes whose distribution depends on soil moisture and salinity. Xerohalophilous scrubs (Arthrocnemum macrostachyum, Suaeda vera subesp. braun-blanquetii, Limonium latebracteatum) and grasses, particularly Lygeum spartum, predominate in saline soils, together with ephemeral plants (Frankenia pulverulenta, Sphenopus divaricatus, Halopeplis amplexicaulis, Salicornia patula, Microcnemum coralloides). Other than the playas, the floors of the wetlands in depressions have xerohalophilous and halonitrophilous scrubs and grasses, interspersed with meadows of halophilous therophytes or tamarisk communities (Tamarix canariensis).

\section{MATERIALS AND METHODS}


Figure 2 gives an overview of the methodology followed in this study. The first step was to produce an updated georeferenced inventory of the MSW. Their delineation in the field was based upon surveys of vascular flora conducted between 2004 and 2009 (Conesa et al., 2011). The cartography of vegetation was carried out in the field using a GPS and mapping in the field on 1:6,000 scale color orthophotographs. Map legend was based on the hierarchical classification of European habitats developed by the CORINE Biotopes Manual (Commission of the European Communities, 1991). The distribution of halophilous and halo-nitrophilous communities were used as evidence for soil salinity related to saline groundwater discharge. The MSW maps of the habitats recorded in the field were treated using ArcGis ${ }^{\circledR}$.

Apart from the very limited sight due to the flatness of the landscape, the main difficulty encountered in the recognition of some depressions in the field was the destruction of their vegetation and the blurring of their geomorphic expression by centuries of agricultural use and the recent generalized earth movements with heavy machinery. To overcome this difficulty we used photointerpretation and topography. Photointerpretation was based on two sets of historical aerial photographs taken in 1927 (1:10,000 scale) and $1957(1: 33,000$ scale), which were previously georeferenced, and three sets of orthophotographs ( 0.5 to $1 \mathrm{~m}$ per pixel) taken in 1997, 2000, and 2006. Historical and current photographs were analyzed in a geographical information system. Soils prospection currently in progress helped to identify saline depression with plowed floors, by determinations of the electrical conductivity in soil extracts (Serrate, 2009; Castañeda et al., 2010). 
The outlines of the MSW were refined using a 1:5000-scale topographic map with a 5mcontour interval, and two complementing digital terrain models, SIGOE (SIG Oleícola Español) from a 1997 flight, which has a 20-m pixel size and an absolute vertical error $<5 \mathrm{~m}$, and PNOA (National Aerial Orthophotography Plan) from a 2006 flight, which has a 5-m pixel size and an absolute vertical accuracy of $1-2 \mathrm{~m}$ in terms of RMSE at $68 \%$ confidence level.

Subsequently, we established sectors in the platform based on hydrogeological and geological maps. The hydrogeological units were extracted from the 1:50,000 scale printed lithological map (Salvany et al., 1996) digitized for this purpose (Figs. 1; 2). The Holocene materials infilling the depressions and flat-bottom valleys, as extracted from the 1:50,000 scale official geological maps (Ramírez, 1997; Solà and Costa, 1997). Additionally, we used the available records of water occurrence in the saline depressions (Herrero and Castañeda, 2009).

The MSW physiognomics and morphometrics were derived using common operations of ArcGis ${ }^{\circledR}$ and TAS software (Lindsay, 2005). They were the following: area (A), perimeter (P), elevation (a.s.1.) of the centroid (E), depth (D) derived from topographic data and calculated as the difference between the lowest and the highest points within each MSW, and proportion $(\%)$ of the saline wetlands covered by vegetation $(\mathrm{V})$. The morphology of the wetlands was characterized by the elongation (L) and the margin irregularity (M), which are non-dimensional indexes. $\mathrm{L}$ was the ratio between the maximum length and maximum width, drawn orthogonally, which yields a value of 1 when the basin is perfectly round. The margin irregularity index or development of shoreline measured the sinuosity of 
the perimeter of the basin (Hutchinson, 1957) and was calculated as $M=P / 2 \sqrt{\pi \mathrm{A}}$, (with 1 , the minimum value, for a circle).

We classified the MSW in terms of: i) wetlands type, ii) geologic features, and iii) water occurrence and vegetation. Descriptive statistics and PCA analysis were calculated using Minitab ${ }^{\circledR}$ and $\operatorname{SSPS} \AA$.

\section{RESULTS}

\section{Extent and physiognomy of saline wetlands}

The 149 saline wetlands that we delineated in the field covered $19.16 \mathrm{~km}^{2}$, a $9 \%$ of the area $\left(\sim 220 \mathrm{~km}^{2}\right)$ of the platform. Thus, the density was 0.7 wetlands $\mathrm{km}^{-2}$ and the pitting index (the reciprocal of wetlands area / total area; Day, 1983) was 11.1. The average size of the wetlands was $0.13 \mathrm{~km}^{2}$ (range $=0.610^{-2} \mathrm{~km}^{2}$ to $2.40 \mathrm{~km}^{2}$ ) and $95 \%$ were $<0.40 \mathrm{~km}^{2}$. A distribution pattern of the wetlands regarding their size was not observed. The largest depressions were located in the center of the platform (Fig. 1), aligned with well-developed flat-bottom valleys. Size was significantly $(p<0.001)$ negatively correlated with elevation $(\mathrm{r}=-0.35)$.

The elevation (E) of the MSW ranged from $315 \mathrm{~m}$ to $367 \mathrm{~m}$ a.s.1. but most $(78 \%)$ of the wetlands floors were within a 30-m range in elevation (between 330m and 360m a.s.1.); 
about $8 \%$ of the MSW were above $360 \mathrm{~m}$ and on the southern platform; and $14 \%$ were below 330m, which were in the northern and central platform. Only three of the wetlands were below $320 \mathrm{~m}$. The elevation and elongation of the wetlands were not significantly correlated. Most of the elongated (L>2.5) MSW occurred at intermediate elevations (330 $350 \mathrm{~m}$ ) and, on average, the wetlands above $350 \mathrm{~m}$ were more circular (median $\mathrm{L}=1.5$ ).

The depth (D) of the MSW ranged from $0.3 \mathrm{~m}$ to $25.8 \mathrm{~m}$ and $78 \%$ of the wetlands were $<5 \mathrm{~m}$ deep (Fig. 3). Only three of the largest wetlands (La Playa, Pito, and Larga) were deeper than $20 \mathrm{~m}$, although their morphometrics differed. The depth of the saline wetlands was significantly $(\mathrm{p}<0.001)$ correlated with the area $(r=0.59)$ and the best fitting $\left(\mathrm{R}^{2}=0.62\right)$ was attained by a potential curve $\left(y=1.06 \mathrm{x}^{1.33}\right)$ (Fig. 3). Some MSW, such as Benamud and Agustín, which are in valley bottoms, differed by their high size to depth ratio. The smallest depressions $(\mathrm{A}<4$ ha) were shallow (mean $\mathrm{D}<2 \mathrm{~m})$.

The elongation index (L) allowed grouping the MSW in four types, from circular to elongated (Table 1). The average $\mathrm{L}$ was $1.8($ range $=1.0-4.4)$, and a high proportion $(39 \%)$ of the wetlands had an elongated or subelongated shape. About $40 \%$ of the MSW had a circular shape; however, because the maximum width (i.e. the maximum distance between margins measured relative to the maximum length) used to calculate L usually is shorter than the mean width (size to maximum length ratio, Hutchinson, 1957), L tends to underestimate, slightly, the degree of elongation. L was not significantly correlated with the size or the elevation of the MSW. 
The average margin irregularity index $(\mathrm{M})$ of the MSW was $1.27+0.2 \mathrm{SD}$ (range= $1.02-$ $1.83)$, and $M$ was significantly $(\mathrm{p}<0.001)$ correlated with the elongation index $(r=0.55)$ and depth $(r=0.45)$. Using the criteria of Hutchinson (1957) and Timms (1992), about 11\% of the MSW had a perfect doline geometry $(1.00<\mathrm{M}<1.25)$, and $29 \%$ had $1.25<\mathrm{M}<$ 1.50 , which indicated dolines modified by deflation. The shapes of the remaining $(60 \%)$ MSW were very close to subcircular.

The PCA analysis for the seven physiognomic descriptors analyzed (A, E, L, D, M, P, and V) produced clear results (Table 2). The varimax PCA revealed that the three first components, with eigenvalues $\geq 1$, accounted for $77 \%$ of the total variability of wetlands physiognomy. The variability explained by each descriptor with these three factors was high for all the descriptors except for elongation (Table 2), ranging from $64 \%$ for depth up to $96 \%$ for elevation. Factor 1 was size, with the maximum contributions of perimeter and area, and showing their predictable positive intercorrelation. High PC1 values are related to large wetlands. Elevations showed a negative contribution, in agreement with the statistically significant negative correlation between area and elevation mentioned above. Elongation totally loaded on factor 2, showing an inevitable intercorrelation with margin irregularity index. Vegetation was the only variable supporting factor 3. This analysis identified the main physiognomic descriptors (A, E and V) and corroborated their direct correlations.

\section{Playa-lakes and other wet saline basins}


Table 3 summarizes the main attributes of playa-lakes and the other wet saline basins. Almost 9\% of the MSW were playa-lakes (Sensu Brière, 2000), which represented the most developed morphological expression of the geological processes. Their mean and median surfaces were $0.47 \mathrm{~km}^{2}$ and $0.27 \mathrm{~km}^{2}$, respectively, and they are the most obvious depressions. A barren floor is their distinctive facies (Castañeda et al., 2005), which was $30 \%-84 \%$ of the total area of each playa. Playa-lakes were the product of an advanced stage of bedrock karstification and deflation. They were discharge playas (sensu Yechieli and Wood, 2002), although it is possible that brine percolated into the groundwater system (Samper-Calvete and García-Vera, 1998). The size of the playas and their drainage basins were not significantly correlated (Castañeda and Herrero, 2005).

From 1987 to 1990 , the flooding frequencies of all the playas ranged from $40 \%$ to $82 \%$, based on field monthly monitoring (Berga, 1993), and from 1993 to 1997, the flooding frequencies ranged from $48 \%$ to $78 \%$, based on field weekly monitoring (Castañeda, 2002; Castañeda et al., 2005). From 1984 to 2004, the water occurrence of playas based on remote sensing ranged from $40 \%$ to $100 \%$ (Herrero and Castañeda, 2009) . No relationship was found between the flooding frequencies of wetlands and their area and elevation. For the three periods surveyed using different temporal scales, The Salineta and La Playa wetlands, with a similar low elevation $(325.1 \mathrm{~m})$, had the highest flooding frequencies, $100 \%$ and $85 \%$, respectively.

The brines reach concentrations $>400 \mathrm{~g} \mathrm{~L}^{-1}$. Those harsh conditions prevent perennial halophytes from becoming established; however, where the flooding frequency is less, the floor is colonized by Arthrocnemum macrostachyum, which is the most salt tolerant 
perennial halophyte in Monegros (Herrero, 2008; Conesa et al., 2011; Domínguez et al., 2013a). Depending on the amount of precipitation, several wet-dry cycles per year are common in playa-lakes. Because of the unpredictable and rapidly changing moisture levels on the floors of the playa-lakes, they are most commonly colonized by hypersaline microbial mats and annual succulent halophytes (Halopeplis amplexicaulis) that can respond to changes in moisture by rapidly germinating, maturing, and setting seed. Perennial prairies are restricted to the margins of the playas where they extend into the lakes from a few to hundreds of meters. Nevertheless, the barren bottom of the playas can be covered by perennial halophytes after several successive dry years, as was the case of Agustín.

In the MSW, the playa-lakes were subcircular, and the mean elongation index (1.7) was slightly lower than the overall mean of the MSW. On average, the playa-lakes were $12 \mathrm{~m}$ deep, and the deepest $(\sim 25 \mathrm{~m})$ was the Pito wetlands, which is in the center of the platform. Many of the playas preserved a cusp-shaped morphology (Fig. 4A) with the cusp pointing upwind indicating unidirectional winds (Goudie and Wells, 1995). As noted by Pueyo (1978/79), the playas were usually flanked by a straight lee side transverse to wind formed by dunes (Fig. 4A). The flat playa floors may expose the bedrock in places at the base of the escarpment (Fig. 4C). The playa floor may be gradually deepened by end-currents erosion towards the leeside (Goudie and Wells, 1995). Under the high flooding frequency regime of the Salineta wetlands, this deepening reaches a bathymetry of $\sim 90 \mathrm{~cm}$.

In $89 \%$ of the MSW, the expression of the hydrologic and geomorphic processes is not as advanced as in the playa-lakes. Those wetlands are less frequently flooded, similar to the 
crypto-wetlands found in coastal environments (Carreño et al., 2008). Groundwater is responsible for their permanently wet soils and the occurrence of halophytes. The surveys of vascular flora were instrumental for identifying many of these wetlands. The mean $\mathrm{M}$ index (1.3) was within the range of dolines modified by deflation (Hutchinson, 1957; Timms, 1992). The wet saline basins had a mean depth markedly lower than that of playas, 5.8m. Several MSW occupied dolines forming a widened portion of flat-bottom valleys.

\section{Distribution of the MSW}

The MSW are located in two hydrogeological systems (Salvany et al., 1996), i.e. the upper and lower aquifer (Samper-Calvete and García-Vera, 1998). The North Endorhreic System (NES) in the northern section of the platform contains 23 wetlands, which are mainly fed by the upper water-table aquifer. Most of those wetlands are in basins that have been excavated in green lutites and are concentrated along the lithological contact between the western gypsum-rich lutites and the eastern carbonate-rich lutites. A few of the NES wetlands occur along the rather continuous thin key layer of red lutites (Fig. 5), which hinders leakage between the upper and lower aquifers (García-Vera, 1996). The South Endorheic System (SES) contains 126 wetlands, which are fed by the lower aquifer and are on a predominantly gypsum and limestone substrate.

At the scale of the geological map and the resolution of the elevation model, ten sectors were identified in this hydrogeological system. The ten resulting MSW groups are characterized by the predominant bedrock composition combined with the mean elevation (Table 4; Fig. 5). In Figure 6 the morphometrics and physiognomics of each group are 
presented for visual comparison using graphical methods (Chambers et al., 1983) for exploratory data analysis (Tukey, 1977).

The NES contained three groups (S1G1, S1G2, and S1G3), which includes the most elongated (mean $\mathrm{E}=2.2$ ) and the shallowest (mean $\mathrm{D}=2.9 \mathrm{~m}$ ) wetlands. The $\mathrm{S} 1 \mathrm{G} 1$ group was within the carbonate-rich lutites of the eastern NES and they had the largest mean area ( $\sim 14$ ha) of the NES wetlands and the lowest mean elevation (327m a.s.1.) of all ten groups (Fig. 7). The S1G3 group was in the gypsum-rich lutites in the western section of the NES. At the base of the upper aquifer, the S1G2 group extended along the red lutitic key layer and had the lowest mean area (7.7ha) and the highest mean elongation $(\mathrm{L}=2.5)$.

About $86 \%$ (1641ha) of the total area of the MSW was within the SES, which contained seven groups (S2G1 to S2G7) whose proportion of limestone bedrock and the mean elevation increased towards the east. S2G1 and S2G2 had predominantly gypsum substrates and low mean elevations $(333 \mathrm{~m}$ and $331 \mathrm{~m}$ a.s.1., respectively), whereas a limestone substrate and an intermediate-high mean elevation (350m a.s.1.) characterized the S2G5 group. The other four groups (S2G3, S2G4, S2G6, and S2G7) were on mixed substrates of gypsum and limestone. The wetlands that had the lowest elevations (Rebollón, Rollico, and Pito) were on gypsum-dominated substrates. All of the SES groups, except the gypsum reach S2G1 and S2G2 groups, were at higher elevations (mean= 350m) than the NES groups (mean $=333 \mathrm{~m}$ a.s.1.).

The mean depth (D) of the SES wetlands $(6.2 \mathrm{~m})$ was almost twice the mean depth of the NES wetlands $(3.3 \mathrm{~m})$. On average, the SES wetlands were subcircular (mean $L=1.7$ ) and 
the NES were elongated (mean $\mathrm{L}=2.2$ ). The mean elongation index of the groups ranged from 1.5 to 1.8 , and was highest in the $\mathrm{S} 2 \mathrm{G} 3$ group. This group was in the west-central section, conspicuously aligned within NW-SE flat bottom valleys.

Excluding the La Playa wetlands (239ha), which was an order of magnitude larger than the other MSW, the mean size of the SES groups ranged from 7.9 to 31.1 ha. The different median size of the NES (6.9ha) and SES wetlands (9.2ha) showed the dissimilarity of distributions and size heterogeneity of the two systems.

\section{Classification of the MSW based on vegetation}

One hundred and fourteen (77\%) of the wetlands had natural vegetation on their floors and/or on their slopes. The mean proportion of each wetlands covered by vegetation was $38 \%$, and ranged from $22 \%$ to $63 \%$ for the groups of wetlands (Fig. 6). The proportion of the wetlands covered by vegetation was not correlated with the size or the elevation of the MSW. The wetlands $<0.20 \mathrm{~km}^{2}$ had the lowest proportions of ground covered byvegetation because their size makes them easier to plow. In 2011, about $35 \%$ of the MSW were plowed and, $42 \%$ of those, had more than half of their area plowed.

Halophytes, both perennials and annuals, were present in $91(61 \%)$ of the MSW. The halophytes are often associated with halonitrophilous plants. The presence / absence of specific vegetation communities allowed clustering the MSW into eight categories (Fig. 5) of decreasing flooding frequency/soil moisture, and soil salinity (Table 5). The available soil data shown in Table 5 corroborate this gradation. Category 1 encloses the typic playa- 
lakes, i.e. wetlands characterized by the occurrence of the most tolerant plants to both soil salinity and flooding. Most playa-lakes concentrate in the sectors of the platform having low mean elevation (S1G1, S2G1, and S2G2) (Fig. 5). The distribution of the wetlands other than category 1 does not reveal any association with the geologic sectors. The relative amount of wetlands of category 8 in S1G2 is due to antropogenic factors, i.e. the on-going transformation of this area into irrigation.

The saline wetlands belonging to the categories 2 through 4 (Table 5) were characterized by the occurrence of perennial halophytes which are less tolerant to flooding. The soil moisture at the bottom of these wetlands is ensured by the proximity of the groundwater, frequently $<1 \mathrm{~m}$. Non flooded wetlands were classified as crypto-wetlands ss. Cryptowetlands types I and II correspond to the presence and absence of pioneering annual halophytes, respectively. The less conspicuous saline wetlands have subtle margins difficult to delineate in the field. They are the most heavily degraded wetlands being partially (category 7) or totally plowed (category 8).

From category 1 to category 8 , the mean elevation increased whereas the percentage of vegetation, depth, area, and margin irregularity decreased. The vegetation communities of the first four categories were diagnostic of saline wetlands. Overall, the soil salinity of wetlands floors was beyond the tolerance of any common cultivated plant.

Key geological features for the distribution of wetlands: confining lutites and valleys network 
The wetlands and flat-bottom valleys are prominent morphodynamic elements of the platform landscape. Typically, the wetlands formed strings, juxtaposed, and coalesced to form uvalas, and a few remained isolated. Wetlands were aligned with valleys or were at their bottoms, which reflect the strong influence of main joint-set orientation, NW-SE, in the Miocene bedrock (Arlegui and Soriano, 1998) which affects: i) the distribution of depressions and valleys, and ii) the orientation of the maximum length of the wetlands. The influence of the secondary joint-set orientation, NE-SW (Arlegui and Soriano, 2003) on the development and the morphology of the wetlands is especially evidenced in the southwestern sector of the platform by the playa-lakes which developed their maximum length in the NE-SW orientation (e.g. Camarón and Rollico), and by the NE-SW alignment of wetlands within each group (Fig 5).

The predominant NW-SE orientation of the valleys and wetlands coincides with the NWSE direction of the prevailing winds and the contour of the water table modeled by Samper and García-Vera (1998). The common lateral changes of the lithological facies (Quirantes, 1978) suggest the influence of lithological changes on the distribution of the wetlands. This is evidenced by the NES wetlands spread along the contact line between the two lutitic facies.

Some of the straight infilled valleys that cross the NES system have a rather continuous and parallel or subparallel drainage pattern typical of materials that have low permeability and vegetation-free terrain. Most of those valleys flow into closed depressions at the SES system. This ending of valleys at swallow holes is a frequent geomorphological feature of gypsum karst areas (Sauro, 1996; Ford and Williams, 2007). Moreover, a ghost drainage 
pattern (Fig. 5), apparent in many aligned wetlands, was inferred from digital terrain models. The largest NW-SE flat bottom valleys extend $>10 \mathrm{~km}$ toward the border of the platform and are noticeable in the field. A few of the valleys are oriented along the NE-SW secondary trend of regional joints. The largest dolines (La Playa, Pueyo, and Pito) were at the confluence of the two join sets, in the central platform. They were at a low elevation (320m) and were the deepest $(>25 \mathrm{~m})$.

The floors of 13 of the SES wetlands were underlain by the impermeable red lutitic key layer (Solà and Costa, 1997). Most of those "red-lutites" wetlands were subelongated (mean $\mathrm{E}=1.8)$, of variable size and depth, and had high elevations because of the slight $\left(1^{\circ}\right.$ $2^{\circ}$ ) northward tilting of the platform.

\section{DISCUSSION}

\section{Updated inventory and delineation of the MSW}

The integration of historical and current data from various sources yielded a map that identified 149 saline wetlands in Monegros that, collectively, were highly consistent with the 130 dolines and the infilled valleys with Holocene materials drawn in the geological maps of Ramírez (1997) and Solà and Costa (1997), and completed the early sketch of Balsa et al. (1991) containing 99 wetlands non georeferenced. The morphology of the basins exhibited several degrees of excavation which ranged from small hollows and smooth depressions to distinct sinkholes that were $>20 \mathrm{~m}$ deep. The topographic data 
derived from the digital elevation models provided subtle topographic details that were not discernible in the field. Aerial photography is a valuable resource for identifying the potential locations for wetlands based on soil surface colors and textural differences in the images, most of them undetectable by eye in the field.

The elevation range where most wetlands concentrated $(\sim 30 \mathrm{~m})$ nearly coincided with the thickness of the gypsum-rich unit (40m, Salvany et al., 1996) bounded by the two red lutite layers (Figs. 1; 5), and with the elevation range where the saturated levels concentrated (Berga, 1993). The flooding frequency of wetlands (with highest values in Salineta and La Playa), as extracted form field surveys and remote sensing, was consistent with the discharge areas identified using hydrogeological modeling (García-Vera, 1996; SamperCalvete and García-Vera, 1998). The lack of relationship between the flooding frequencies of wetlands and their size and elevation suggested that flooding frequency can be related with their location along preferential groundwater flows.

Hydrology, soils, and vegetation are the factors that permit the delineation of wetlands, even in arid environments (Brostoff et al., 2001); however, centuries of agriculture, land consolidation in the $1980 \mathrm{~s}$, and the development of new irrigation systems make it difficult to delineate wetlands in Spain. Saline wetlands are recognized easily on soil maps because of their distinctive soils, which differ considerably from the soilscapes of plains and slopes (Castañeda et al., 2010; Moret-Fernández et al., 2013). In the absence of soil maps, the presence and nature of the vegetation aids the identification and delineation of wetlands. A persistent, shallow, fluctuating saline water table at the bottoms of the MSW, even when surface water is not present, maintains the high soil salinity, which varies spatially as 
reflected by the distribution of plant communities. The halophilous vegetation was a diagnostic criterion for many wetlands identification. The surveys of vascular flora were essential in substantiating previous inventories and the information in historical aerial photography, and for delineating the wetlands and identifying crypto-wetlands that had degraded morphologies. Probably, the inventoried wetlands surface is a minimum estimate if it is assumed that the visible wetlands margins have shrunk because the vegetation has been removed. In those areas, soil salinity transects and electromagnetic induction surveys (Serrate, 2009) can overcome the problems of ambiguous indicators of wetlands function.

The proportion of the platform covered by wetlands in Monegros was similar to the proportion found in a stretch of the Ebro River Valley 70km upstream that was covered by alluvial sinkholes and is also on the Zaragoza Gypsum Formation (Galve et al., 2009). In that area, the hydrological setting and formation mechanisms differ from the MWS, particularly, the influence of alluvial aquifers and the centuries-old practice of surface irrigation using unlined ditches. On the platform of the MSW, a significant, continuous water input into the evaporitic bedrock was absent until 2011, although irrigation systems were going to operate in half of the platform. Thus, an increase in bedrock dissolution might occur in response to irrigation, especially because of: i) the exposed, densely fractured bedrock, ii) the shallow calcareous and gypseous soils, and iii) an increase in the water dissolution potential caused by the mixing of fresh irrigation water $\left(<0.1 \mathrm{dS} \mathrm{m}^{-1}\right)$ and the existing hypersaline groundwater $\left(>100 \mathrm{dS} \mathrm{m}^{-1}\right)$.

The mean size of the MSW (13ha) was greater than the average size of the playas in the High Plains (7.6ha) (Smith, 2003), though wetlands density was similar (0.7 and 0.4 
playas $/ \mathrm{km}^{2}$ for MSW and the High Plains, respectively). In contrast, the MSW density was much lower than the densities reported by Gracia-Prieto (1991) $\left(6.5-35\right.$ dolines $\left./ \mathrm{km}^{2}\right)$ in other Spanish karstic doline fields on limestone. The relatively high proportion (9\%) and mean size (13ha) of the Monegros wetlands compared to limestone karstic doline fields (Gracia-Prieto, 1991) is a result of intense karstification over a moderately small area $\left(\sim 220 \mathrm{~km}^{2}\right)$, probably, enhanced by the solubility of gypsum in the Monegros area, which can be favored by the occurrence of lithogenetic fissures (Klimchouk and Andrejchuk, 1996).

The predominantly subelongated shape of the MSW reflects their origin and a geometry strongly influenced by fractures, which is unlike the High Plain playas roundness caused by surface runoff (Sabin and Hollyday, 1995). A relationship between the area of the wetlands and the lithology did not exist because of the presence of interbedded gypsum, limestone, and clay facies, and the frequent lateral and vertical shifts in the facies throughout the platform (Quirantes, 1978). Large depressions were common in platform sectors where gyprock was predominant, and the two wetlands groups (S2G5 and S2G7) that had the smallest average sizes formed in platform sectors where limestone predominated (Figs. 1; $5)$.

The excavating of the basins is expected to be limited once impermeable layers are reached. The 14 MSW with floors that reached the impermeable red lutitic layer that underlies the SES did not share common hydrological features. Those "red-lutites wetlands" included playa-lakes and wet depressions that were twice as deep as and larger (most $>20 \mathrm{ha}$ ) than the average MSW. 


\section{Wetlands relationships and causal factors}

The PCA analysis pointed out the correlations between the individual variables and suggests that a higher number of variables will probably give enhanced weighted factors and decrease the redundancy on basins geometry (Table 2). Intra-group variation in depth, elongation, and vegetation cover (Fig. 6) explains the lack of significant differences in the geometric attributes of the basins. Significant differences in morphometrics only occurred between sectors that had very dissimilar values. Unlike the elevations of the MSW, which are stable, those geometric features were altered by anthropogenic factors (Castañeda and Herrero, 2008). Many differences between sectors arise from elevation (Fig. 6). Based on Tukey's Test at $p<0.005$, elevation differed significantly between the wetlands which were on limestone rich sectors (S2G3 through S2G7 groups), and those which were on a gypsum rich substrate in S2 (S2G1 and S2G2) and most S1 wetlands. The S2G7 group, which had the highest mean elevation, differed significantly from the other groups.

In Monegros, the origin and development of the basins in a mixed carbonate and gypsum karst is strongly influenced by the lithology of the bedrock. Overall, the depth and elevation of the wetlands were not correlated; however, when analyzed within sectors (with S1 groups pooled), each fit a power function of the form $y=a x^{b}$, with $x$ : excavation depth, $y$ : elevation, and $b$ : ranging from -0.005 to -0.031 . Power functions have been widely used in landform studies to correlate variables (Denizman and Randazzo, 2000). In Figure 7, the curvatures were similar among all of the groups except S1 and S2G5. The pronounced curvature of the S1 system indicates the strong effect of elevation on depth, and the flat 
curve of the S2G5 group indicates the weak relationship between those parameters. The lutite-rich substrate and the elongated shape $(\mathrm{L}=2.1)$ of the wetlands in the $\mathrm{S} 1$ groups contrasted the predominant limestone substrate and pronounced circularity $(\mathrm{L}=1.47)$ of S2G5 wetlands, probably, because of differences in the mechanisms of excavation. The S2G5 wetlands developed by limestone dissolution with negligible deflation and runoff, while the lutitic substrate of the S1 wetlands is prone to deflation, and runoff can be more intense because they are at relatively low elevations.

In addition, the wetlands groups differed in how well they fit their curves. The limestonerich groups S2G6 and S2G7 $\left(\mathrm{R}^{2}=0.73\right)$ and the gypsum-rich group S2G1 $\left(\mathrm{R}^{2}=0.64\right)$ exhibited the best fit. All the other groups had $\mathrm{R}^{2}<0.50$. The strong fit of some of the groups suggested that their behaviors were similar, possibly because of their relatively homogeneous substrates. The dissimilarity between the S1 and the S2 groups is consistent with the grouping in two different systems and with the hydrological role of the key layer of red lutites between the NES and SES wetlands (Fig. 5).

The power function family observed in our study was consistent with the hypothesis of Sánchez et al. (1998) which posited that depressions enlarge with age and maturity, and involve dissolution of the bedrock and subsidence. In addition, that model applies to basin size, which increased with depth (Fig. 3). Most of the deep playa-lakes were at low elevations; however, shallow basins were not restricted to the highest elevations. The model was applicable only within groups (Fig. 7) which emphasizes the heterogeneity of the platform, demonstrated by hydrogeologists (García-Vera, 1996). 
In contrast with the intra-group variation of the ten geologic groups of MSW (Fig. 6; Table 2), the eight vegetation-based groups of MSW (Fig. 5; Table 4) were significantly different in vegetation percentage $(p<0.01)$, flooding frequency $(p<0.001)$, and depth $(p<0.05)$, denoting intra-group homogeneity. This finding relies on the difference in scale between the pattern of the geologic groups, determined by long-lasting geomorphic processes, and that of the vegetation-based groups which is based on a much faster process related with the establishment of the plant communities. In regard with this, the correlations between the mean morphometrics of the vegetation-based groups of MSW were more evident. The flooding frequencies of the MSW groups showed a significant $(\mathrm{p}<0.001)$ negative correlation with their elevations $(\mathrm{r}=-0.879)$, and a significant $(\mathrm{p}<0.001)$ correlation $(\mathrm{r}=$ 0.939) with their sizes (Fig. 8), indicating that wetlands maturity and function were better expressed on the largest dolines and at lowest elevations.

The percentages of vegetation were significantly correlated with depth $(r=0.757, p<0.05)$, and with perimeter $(r=0.718, p<0.05)$ and margin irregularity $(r=0.839, p<0.01)$. These relationships (Fig. 8) indicate that the conservation of the vegetation is controlled by the deepness and the irregularity of the dolines shape, in consistence with the fact that the destruction of the vegetation has been more intense in shallow dolines.

\section{Distribution patterns of the MSW and implications}

The flat-bottom infilled valleys, most of which did not have a creek, were difficult to identify in situ because of the relatively smooth topography and the agricultural imprint. The continuous detailed topography provided by digital elevation models along with aerial 
photographs are advantageous in identifying the network of valleys, the association valleysdolines, and the chains of dolines in the nearly horizontal platform landscape. Wetlands associated with valleys result from the "drying up" of pre-existing valleys (Sauro, 1996; Ford and Williams, 2007). Similar associations of dolines-valleys occur elsewhere in the Ebro Basin, when a very low structurally-controlled topographic gradient occurs. In Monegros, the valleys did not appear active because downstream run-off was scarce and the infilling has been dated to the Late Pleistocene-Holocene in nearby areas (Sancho et al., 2011). The capturing of the surface drainage network by small dolines has been evidenced in other areas by the alignment of dolines and sinkholes as the only evidence of the original fluvial drainage (Calaforra and Pulido-Bosch, 2003). However, no overall patterns could be determined in other gypsum karst areas as in Southern Spain (Calaforra and Pulido-Bosch, 1999) where a chaotic structure prevails without alignment of the principal axes of the dolines.

In applying the classical endorheic model to the platform in Monegros, most of the previous authors assumed that the MSW were isolated basins because of the absence of surface hydrological connections. Nevertheless, the analysis of the MSW patterns reveals a defined infrastructure based on the dry valleys network, indicating that a subsurface connection exists between depressions and dry valleys, as suggested by: i) the alignments of the basins following joints in continuity and combined with infilled valleys, ii) the large size of the recharge area of some of the MSW (Agustín, 5km long, García-Vera, 1996), and iii) the mineralogical (Mees et al., 2011, 2012) and hydrological (Castañeda and Herrero, 2005) similarities between neighboring wetlands. Previous hydrogeological studies (Berga, 
1993; Álvarez, 1996; Samper-Calvete and García-Vera, 1998) demonstrated preferential flows through subsurface layers.

\section{CONCLUSION}

Our wetlands classification based upon abiotic (geology) and biotic (habitats) features was an approximation to the delineation of land units. The present study has provided saline wetlands grouping for functionality, thus, simplifying the platform system and reducing the apparent complexity of habitats capable of rapid change over time and space. The morphometric analyses of the basins indicated the platform is very complex because of the intricate geomorphic structure of the wetlands basins together with the network of infilled valleys. The spatial connection patterns between the MSW and the valleys network provide preferential ways for water flows. Our grouping of MSW in different sectors related to geological and vegetation features provide a predictable relationship of surficial processes with otherwise complex and undetectable hydrological connectivity. A better understanding of the MSW distribution patterns can support the design and management of irrigation schemes. Heavy ecological effects of water application can be foreseen even in the areas excluded of irrigation, due to the internal connection between wetlands.

A hypothesis for the entire platform should include the current distribution of wetlands in Monegros and a model based on karstic erosion that preferentially removes gypsum and develops wetlands and valleys. This approach would help to explain and to predict the hydrological dynamics. 
Our approach can be implemented in other regions around the world for integrating the geological and ecological factors driving the evolution of wetlands. Sound generalizations about the wetlands in Monegros and their distribution will allow the development of management guidelines and will be helpful for the soil surveys needed to reconcile the protection of wetlands with the new on-farm irrigation developments.

\section{ACKNOWLEDGEMENTS}

This study was part of project AGL2012-40100 funded by the Spanish Government, and 2012/GALC-036. First author was co-financed with European Social Funds.

\section{REFERENCES}

Álvarez, M., 1996. Estudio hidrogeológico complementario de los sectores VII, IX, XI y ampliación a los sectores X y XII de la zona regable de los Monegros II (Zaragoza y Huesca). Informe final, Tomo I-Memoria. Madrid (Spain), Ministerio de Agricultura, Pesca y Alimentación, Dirección General de Planificación y Desarrollo Rural, 102pp.

Arlegui, L.E., Soriano, M.A., 1998. Characterizing lineaments from satellite images and field studies in the central Ebro basin. International Journal of Remote Sensing, 19, 3169-3185.

Arlegui, L.E., Soriano, M.A., 2003. An example of a comparison between Thematic Mapper and radar images in the central Ebro basin. International Journal of Remote Sensing, 24, 457-474. 
Balsa, J., Guerrero, C., Pascual, M.L., Montes, C., 1991. Las saladas de Bujaraloz-Sástago y las saladas de Chiprana: riqueza natural de Aragón. Empelte, 7, 1-30.

Benito, J.L., 2011. Cartografía de los hábitats CORINE de Aragón. Lista de hábitats de Aragón, v. 4.09. Monografías de Botánica Ibérica, 7, 90pp. Available at http://www.jolube.net/

Berga, A., 1993. Relaciones clima-agua-suelo-subsuelo en Monegros II. Doctoral Thesis. Spain, University of Lleida, 392pp.

Bowler, J.M., 1986. Spatial variability and hydrologic evolution of Australian lake basins: analogue for Pleistocene hydrologic change and evaporite formation. Palaeogeography, Palaeoclimatology, Palaeoecology, 54, 21-41.

Brière, P.R., 2000. Playa, playa lake, sabkha: Proposed definitions for old terms. Journal of Arid Environments, 45, 1-7.

Brostoff, W., Lichvar, R., Sprecher, S., 2001. Delineating playas in the Arid Southwest. A literature review. ERDC TR-01-4. 25pp.

Calaforra, J.M., Pulido-Bosch, A., 1999. Gypsum karst features as evidence of diapiric processes in the Betic Cordillera, Southern Spain. Geomorphology, 29, 251-264.

Calaforra, J.M., Pulido-Bosch, A., 2003. Evolution of the gypsum karst of Sorbas (SE Spain). Geomorphology, 50, 173-180.

Carreño, M.F., Esteve, M.A., Martínez, J., Palazón, J.A., Pardo, M.T., 2008. Habitat changes in coastal wetlands associated to hydrological changes in the watershed. Estuarine, Coastal and Shelf Science, 77, 475-483.

Castañeda, C., 2002. El agua de las saladas de Monegros estudiada con datos de campo y de satélite. Zaragoza, Consejo de Protección de la Naturaleza, 158pp.

Castañeda, C., García-Vera, M.A., 2008. Water balance in the playa-lakes of an arid environment, Monegros, NE Spain. Hydrogeology Journal, 16, 87-102.

Castañeda, C., Herrero, J., 2005. The water regime of the Monegros playa-lakes as established from ground and satellite data. Journal of Hydrology, 310, 95-110. 
Castañeda, C., Herrero, J., 2008. Assessing the degradation of saline wetlands in an arid agricultural region in Spain. Catena, 72, 205-213.

Castañeda, C., Herrero, J., Casterad, M.A., 2005. Landsat monitoring of playa-lakes in the Spanish Monegros Desert. Journal of Arid Environments, 63, 497-516.

Castañeda, C., Mendez, S. Herrero, J., Betrán, J., 2010. Investigating soils for agri-environmental protection in an arid region of Spain. In: Zdruli, P., Pagliai, M., Kapur, S., Faz, A. (eds.). Land Degradation and Desertification: Assessment, Mitigation and Remediation. SpringerVerlag. ISBN: 978-90-481-8656-3.

Chambers, J.M., Cleveland, W.S., Kleiner, B., Tukey, P.A., 1983. Graphical Methods for Data Analysis. Chapman and Hall, New York.

Commission of the European Communities, 1991. CORINE Biotopes Manual. Habitats of the European Community. Office for Official Publications of the European Communities, 426pp.

Conesa, J.A., Castañeda, C., Pedrol, J., 2011. Las saladas de Monegros y su entorno. Hábitats y paisaje vegetal. Zaragoza (Spain), Consejo de Protección de la Naturaleza de Aragón, 539pp.

Dantín, J., 1929. Localización de las zonas endorreicas de España. Memorias de la Real Sociedad Española de Historia Natural, XV, 829-836.

Day, M., 1983. Doline morphology and development in Barbados. Annals of the Association of American Geographers, 73, 206-219.

Dantín, J., 1942. Distribución y extensión del endorreísmo aragonés. Estudios Geográficos, 3(8), $505-595$.

Denizman, C., Randazzo, A.F., 2000. Post-Miocene subtropical karst evolution, lower Suwannee River basin, Florida. Geological Society of America Bulletin, 112, 1804-1813.

Domínguez, M., Castañeda, C., Herrero. J., 2013a. Two microenvironments at the soil surface of saline wetlands in Monegros, Spain. SSSAJ, DOI:10.2136/sssaj12.0014 
Domínguez, M., Herrero, J., Castañeda, C., 2013b. Saline wetlands fate in inland deserts: an example of eighty years decline from Monegros, Spain. Land Degradation and Development, DOI: $10.1002 / 1 \mathrm{dr} .1122$.

Dugid, A., Barnetson, J., Pavey, C., Albrecht, D., Risler, J., McNellie, M., 2002. Wetlands in the arid Northern Territory. A report to Environment Australia on the inventory and significance of wetlands in the arid NT. (Parks and Wildlife Commission of the Northern Territory, Alice Springs).

Ford, D., Williams, P., 2007. Karst Hydrogeology and Geomorphology [Rev. ed.]. John Wiley \& Sons Ltd., 562pp.

Galve, J.P., Gutiérrez, F., Lucha, P., Bonachea, J., Remondo, J., Cendrero, A., Gutiérrez, M., Gimeno, M.J., Pardo, G., Sánchez, J.A., 2009. Sinkholes in the salt-bearing evaporite karst of the Ebro River valley upstream of Zaragoza city (NE Spain). Geomorphological mapping and analysis as a basis for risk management. Geomorphology, 108, 145-158.

García-Vera, M.A., 1996. Hidrogeología de zonas endorreicas en climas semiáridos. Aplicación a los Monegros (Zaragoza y Huesca). Zaragoza, Consejo de Protección de la Naturaleza en Aragón, 297pp.

González-Sampériz, P., Valero-Garcés, B.L., Moreno, A., Morellón, M., Navas, A., Machín, J., Delgado-Huertas, A., 2008. Vegetation changes and hydrological fluctuations in the Central Ebro Basin (NE Spain) since the Late Glacial period: saline lake records. Palaeogeography, Palaeoclimatology, Palaeoecology, 259, 157-181.

Goudie, A.S., Wells, G.L., 1995. The nature, distribution and formation of pans in arid zones. Earth Science Reviews, 38, 1-69.

Gracia-Prieto, J., 1991. Criterios de clasificación morfométrica de campos de dolinas. Cuaternario y Geomorfología, 5, 65-76.

Gutiérrez-Elorza, M., Desir, G., Gutiérrez-Santolalla, F., 2002. Yardangs in the semiarid central sector of the Ebro Depression (NE Spain). Geomorphology, 44, 155-170. 
Herrero, J., 2008. Salinidad edáfica en varios salobrares de Aragón. Madrid, Memorias de la Real Sociedad Española de Historia Natural, Tomo IV, 164pp.

Herrero, J., Castañeda, C., 2009. Delineation and functional status monitoring in small saline wetlands of NE Spain. Journal of Environmental Management, 90, 2212-2218.

Herrero, J., Snyder, R.L., 1997. Aridity and irrigation in Aragón, Spain. Journal of Arid Environments, 35, 55-547.

Hollis, G.E., 1990. Environmental impacts of development on wetlands in arid and semi-arid lands. Hydrological Sciences, 35, 4-8.

Hutchinson, G.E., 1957. A Treatise on Limnology. Volume 1. New York, John Wiley \& Sons, $1014 p p$.

Klimchouk, A., Andrejchuk, V., 1996. Sulphate rocks as an arena for karst development. International Journal of Speleology, 25, 9-20.

Lindsay, J.B., 2005. The Terrain Analysis System: a tool for hydro-geomorphic applications. Hydrological Processes, 19, 1123-1130.

Lines, G.C., 1979. Hydrology and surface morphology of the Bonneville Salt Flats and Pilot Valley playa, Utah. US Geol Surv Water-Supply Pap 2057.

McEwan, K., Jolly, I., Holland, K., 2006. Groundwater-surface water interactions in arid/semiarid wetlands and the consequences of salinity for wetlands ecology. Australia, CSIRO Land and Water, 36pp.

Mees, F., Castañeda, C., van Ranst, E., 2011. Sedimentary and diagenetic features in saline lake deposits of the Monegros region, northern Spain. Catena, 85, 245-252.

Mees, F., Castañeda, C., Herrero, J., van Ranst, E., 2012. The nature and significance of variations in gypsum crystal morphology in dry lake basins. Journal of Sedimentary Research, 82, 4556. 
Moret-Fernández, D., Castañeda, C., Paracuellos, E., Jiménez, S., Herrero, J. Hydro-physical characterization of contrasting soils in the Monegros drylands, Spain. Journal of Hydrology, 486, 403-411.

Pedrocchi, C., 1998. Ecología de Los Monegros. Huesca, Inst. Est. Altoaragoneses, 430pp.

Pueyo, J.J., 1978/79. La precipitación evaporítica actual en las lagunas saladas del área: Bujaraloz, Sástago, Caspe, Alcañiz y Calanda (provincias de Zaragoza y Teruel). Diputación Provincial and Universitat de Barcelona, Revista del Instituto de Investigaciones Geológicas, 33, 5-56.

Quirantes, J.J., 1965. Nota sobre las lagunas de Bujaraloz-Sástago. Geographica, 12, 30-34.

Quirantes, J.J., 1978. Estudio sedimentológico y estratigráfico del Terciario continental de los Monegros. Zaragoza, Institución Fernando el Católico (CSIC), 200pp.

Ramírez, J.I., 1997. Mapa Geológico de España, Escala 1:50,000, Hoja 413. Madrid, Instituto Geológico y Minero de España (IGME), 78pp.

Ramsar Convention Secretariat, 2010. Designating Ramsar Sites: Strategic Framework and guidelines for the future development of the List of Wetlands of International Importance, Ramsar handbooks for the wise use of wetlands. Gland (Switzerland), Ramsar Convention Secretariat, 4th edition, volume 17 ,

Sabin, T.J., Holliday, V.T., 1995. Playas and lunettes on the Southern High Plains: morphometric and spatial relationships. Annals of the Association of American Geographers, 85, 286-305.

Salvany, J.M., García-Vera, M.A., Samper, J., 1996. Geología e hidrogeología de la zona endorreica de Bujaraloz-Sástago (Los Monegros, provincias de Zaragoza y Huesca). Acta Geologica Hispanica, 30(4), 31-50.

Samper-Calvete, F.J., García-Vera, M.A., 1998. Inverse modelling of groundwater flow in the semiarid evaporitic closed basin of Los Monegros, Spain. Hydrogeology Journal, 6, 33-49.

Sánchez, J.A., Pérez, A., Martínez-Gil, J., 1998. Combined effects of groundwater and aeolian processes in the formation of the northernmost closed saline depressions of Europe: north-east Spain. Hydrological Processes, 12, 813-820. 
Sancho, C., Muñoz, A., González-Sampériz, P., Osácar, C., 2011. Palaeoenvironmental interpretation of Late Pleistocenee-Holocene morphosedimentary record in the Valsalada saline wetlands (Central Ebro Basin, NE Spain). Journal of Arid Environments, 75, 742-751.

Sauro, U., 1996. Geomorphological aspects of gypsum karst areas with special emphasis on exposed karst. International Journal of Speleology, 25, 105-114.

Schütt, B., 1998. Reconstruction of palaeoenvironmental conditions by investigation of Holocene playa sediments in the Ebro Basin, Spain: preliminary results. Geomorphology, 23, 273-283.

Senger, R.K., Kreitler, C.W., Fogg, G.E., 1987. Regional underpressuring in deep brine aquifers, Palo Duro basin, Texas. 1. The effect of Cenozoic basin development. Water Resoures Research, 23, 1494-1504.

Serrate, L., 2009. Estudio de rasgos edáficos para plantear una nueva medida agroambiental en Monegros. Master Thesis. Zaragoza, Universidad de Zaragoza, 212pp.

Smith, L., 2003. Playas of the Great Plains. Austin, University of Texas Press, 257pp.

Soil Survey Staff, 2010. Keys to Soil Taxonomy. Washington, DC., USDA - Natural Resources Conservation Service, $11^{\text {th }}$ edition,

Solà, J., Costa, J.M., 1997. Mapa Geológico de España, Escala 1:50,000, Bujaraloz (Hoja 414). Madrid,Instituto Geológico y Minero de España, 76pp.

Stafford, K.W., Rosales-Lagarde, L., Boston, P.J., 2008. Castile evaporite karst potential map of the Gypsum Plain, Eddy County, New Mexico and Culberson County, Texas: A GIS methodological comparison. Journal of Cave and Karst Studies, 70, 35-46.

Timms, B.V., 1992. Lake Geomorphology. Adelaide, Gleneglades Publishing, 180pp.

Tukey, J.W., 1977. Exploratory Data Analysis. Reading (Massachusetts), Addison-Wesley,.

Tweed, S., Leblanc, M., Cartwright, I., Favreau, G., Leduc, C., 2011. Arid zone groundwater recharge and salinization; an example from the Lake Eyre Basin, Australia. Journal of Hydrology, 408, 257-275. 
Valero-Garcés, B.L., Martí, C., García-Ruiz, J.M., González-Sampériz, P., Lorente, A., Begueria, S., Navas, A., Machin, J., Delgado-Huertas, A., Stevenson, T., Davis, B., 2001. Lateglacial and early Holocene paleohydrological and environmental change along a humid-arid transect from the Central Pyrenees to the Ebro valley (Spain). Terra Nostra, 3, 211-218.

Williams, W.D., 1996. The largest, highest and lowest lakes of the world: Saline lakes. Verhandlungen-Internationale Vereinigung für theoretische und angewandte Limnologie, 26, $61-79$.

Williams, W.D., 2002. Environmental threats to salt lakes and the likely status of inland saline ecosystems in 2025. Environmental Conservation, 29, 154-167

Yechieli, Y., Wood, W.W., 2002. Hydrogeologic processes in saline systems: playas, sabkhas, and saline lakes. Earth Science Reviews, 58, 343-365. 